\title{
TREATMENT OUTCOME AND EFFICACY OF ANTI-TUBERCULOSIS TREATMENT IN TUBERCULOSIS PATIENTS PUT ON DOTS IN RNTCP IN CENTRAL INDIA
}

\author{
Ratan Kumar ${ }^{1}$, Rajesh Kumar Ahirwar², Lokendra Dave ${ }^{3}$, Nishant Srivastava ${ }^{4}$, Adarsh Bajpai ${ }^{5}$, Sapna Jain ${ }^{6}$, Aditya Gargava $^{7}$, \\ Shyam Krishna Vaish ${ }^{8}$ \\ 1 Professor, Department of Pulmonary Medicine, LN Medical College, Bhopal, Madhya Pradesh. \\ ${ }^{2}$ Associate Professor, Department of Community Medicine, LN Medical College, Bhopal, Madhya Pradesh. \\ 3Professor and HOD, Department of TB \& Chest Disease, Gandhi Medical College, Bhopal, Madhya Pradesh. \\ ${ }^{4}$ Associate Professor, Department of TB \& Chest Disease, Gandhi Medical College, Bhopal, Madhya Pradesh. \\ ${ }_{5}^{5}$ Assistant Professor, Department of Medicine, LN Medical College, Bhopal, Madhya Pradesh. \\ ${ }^{6}$ Associate Professor, Department of Obstetrics and Gynaecology, LN Medical College, Bhopal, Madhya Pradesh. \\ ${ }^{7}$ Assistant Professor, Department of ENT, LN Medical College, Bhopal, Madhya Pradesh. \\ ${ }^{8}$ Medical Officer, New Additional PHC, Mugh, Raha Rudholi, Basti, Uttar Pradesh.
}

\section{BACKGROUND}

ABSTRACT

Tuberculosis (TB) remains a global public health problem and a major cause of death from a single infectious agent among adults in India and other developing countries.

Aims \& Objectives- The aim of this study is to characterise outcome and efficacy of tuberculosis treatment among patients put on DOTS in RNTCP.

\section{MATERIALS AND METHODS}

This is a retrospective study of diagnosed TB patients of all age groups attending OPD of various departments of LN Medical College and JK Hospital, Bhopal, MP (India), between the period of January 2012 and October 2015.

\section{RESULTS}

Total 454 patients were found eligible for this study who were diagnosed and received full course of ATT under DOTS in RNTCP. In different age groups percentages of patients observed were $12.11 \%, 31.27 \%, 22.68 \%, 13.65 \%$ and $20.26 \%$ in 0 - 14 years, $15-25$ years, 26 - 35 years, 36 - 45 years and above 45 years respectively.

\section{CONCLUSION}

Maximum patients, $31.27 \%$ (142/454) were registered in the age group of 15 - 25 years. Overall, treatment outcome were observed as follows- $82.81 \%$ treated successfully, $7.70 \%$ defaulted, $4.18 \%$ failed and $3.96 \%$ died. Higher percentage of treatment was successful (98.18\%) and was observed in the age group of 0 - 14 years, whereas higher percentage of both defaulter (14.13\%) and mortality (13.04\%) with lower treatment success rate $(65.21 \%)$ was observed in the age group of above 45 years. Higher percentage of defaulter, failure and mortality were observed in males and category I in comparison to females and category II.

\section{KEYWORDS}

Treatment Outcome, Anti-Tuberculosis Treatment, DOTS.

HOW TO CITE THIS ARTICLE: Kumar R, Ahirwar RK, Dave L, et al. Treatment outcome and efficacy of anti-tuberculosis treatment in tuberculosis patients put on DOTS in RNTCP in Central India. J. Evolution Med. Dent. Sci. 2018;7(15):1840-1844, DOI: $10.14260 /$ jemds/2018/416

\section{BACKGROUND}

Tuberculosis (TB) remains a global public health problem and major cause of death from a single infectious agent among adults in India and other developing countries[1,2,3] The problem is further compounded by the emergence of HIV, DM and DR (Drug resistance) TB. According to WHO 6.1 million TB cases were reported in 2013, out of which 5.7 million cases were newly diagnosed and another 0.4 million were already on treatment. ${ }^{[4]}$ The burden of TB in India is the highest accounting for approximately one-fifth $(21 \%)$ of the

'Financial or Other Competing Interest': None.

Submission 01-03-2018, Peer Review 25-03-2018,

Acceptance 31-03-2018, Published 09-04-2018.

Corresponding Author:

Dr. Rajesh Kumar Ahirwar,

Associate Professor,

Department of Community Medicine,

LN Medical College, Bhopal, Madhya Pradesh.

E-mail: rattan_vaish@yahoo.co.in

DOI: $10.14260 /$ jemds $/ 2018 / 416$

(c) $($ ) $\$$ global incidence.[5] Every year 1.8 million new cases occur in India, out of which 0.8 million are infectious.[6] As per Revised National Tuberculosis Control Programme (RNTCP) 2011 in Madhya Pradesh, there were 90,764 cases registered for TB. $[7,8]$

In India, National Tuberculosis Control Programme (NTP) was launched in 1962. NTP was integrated and implemented through the general public health services.[9] NTP could not achieve the objective because of low priority, managerial weakness, over dependence on x-ray chest for diagnosis and inadequate funding. In order to overcome the shortcomings in the NTP, WHO and Government of India revised the programme jointly in 1992 . WHO declared TB, a global health emergency in April 1993.[10] The Revised National Tuberculosis Programme (RNTCP) has been implemented in 1993, guided by WHO and supported by world bank.[11]

A five points strategy known as Directly Observed Treatment Short course (DOTS) was launched in India in a phased manner under RNTCP in 1997 with objective of cure rate not less than $85 \%$ of infectious TB cases and at least $70 \%$ 
detection of new cases through quality sputum microscopy.[12,13]

With this background we conducted this retrospective study at LN Medical College and JK Hospital, Bhopal, MP (India) to observe the ground reality of treatment response.

\section{MATERIALS AND METHODS}

\section{Aim}

The aim of this study was to characterise outcome and efficacy of anti-tuberculosis drugs in patients put on DOTS in RNTCP.

\section{Study Design}

This is a retrospective observational study of diagnosed TB patients of all age groups.

\section{Study Areas}

The study was conducted in the LN Medical College and JK Hospital, Bhopal (MP), a tertiary care centre comprising of the patients from urban, nearby villages and adjoining districts who were referred for diagnosis and treatment of tuberculosis.

\section{Study Period}

After getting permission from the authorities and clearance from Institutional Ethical Committee, record and data from RNTCP DOTS centre has been obtained between period of January 2012 and October 2015.

\section{Study Population}

The population includes all 454 patients attending various OPD at LN Medical College and JK Hospital, Bhopal (MP), who were diagnosed clinically/ microbiologically/ pathologically and/ or radiologically as having TB disease and registered for treatment under DOTS during the study period.

\section{Source of Information}

For this study, data has been obtained from DOTS treatment record cards, RNTCP referral register, patient record sheet of hospital and laboratory register.

\section{Inclusion Criteria}

Patients of all age and sex groups registered for category I and II RNTCP DOTS anti-tuberculosis treatment.

\section{Exclusion Criteria}

Any patient having HIV infection and drug resistance tuberculosis.

\section{Definitions}

\section{Cured}

Initially, sputum smear positive patients who have completed treatment and has negative sputum smear on at least two occasions, out of which one at completion of treatment.

\section{Treatment Completed}

Sputum negative pulmonary TB and extrapulmonary TB patient who had received full course of ATT has not become smear positive during or at the end of the treatment.

\section{Defaulted}

The patient who had not taken ATT for one month or more consecutively after one month of starting the treatment.

\section{Failure}

Smear positive cases who remain smear positive at 5 months or more after starting the treatment. Also includes patients who were initially smear negative, but became positive during treatment.

\section{Died}

Patient who died during treatment regardless of cause of death.

\section{Transfer Out}

The patient who has been transferred to another TB unit/ district and for whom the treatment result (outcome) is not known.

\section{Treatment Successful}

The sum of 'cured' and 'treatment completed' patients.

\section{RESULTS}

Total 454 patients were found eligible for this study, who were diagnosed and received full course of ATT under DOTS in RNTCP. Out of total 454 patients, $58.60 \%$ (266/454) were male and 41.40\% (188/454) were female. 80.39\% (365/454) were registered for category I ATT, whereas $19.61 \%$ (89/454) among category II. Patients registered of pulmonary tuberculosis and EPTB were $65.47 \%$ (239/365) and $34.53 \%(126 / 365)$ in category I, whereas $93.25 \%$ (83/89) and 6.75\% (6/89) in category II.

Maximum patients $31.27 \%$ (142/454) were registered in the age group of 15 - 25 years and only $12.11 \%(55 / 454)$ were found in the age group of 0 - 14 years.

Among patients of category I, 32.32\% (118/454) and $26.96 \%(24 / 89)$ in category II were found to be registered in age group of 15 - 25 years. Highest number of patients, $28.19 \%(75 / 266)$ and $35.63 \%(67 / 188)$ of total male and female patients belonged to the same age group (15-25 years). Overall treatment outcome observed is described in Tables 1 to 3 .

\begin{tabular}{|c|c|c|c|c|c|c|c|c|c|}
\hline & $\begin{array}{c}\text { Treatment } \\
\text { Successful } \\
{[\%(\text { No.)] }} \\
82.81 \% \\
(376)\end{array}$ & $\begin{array}{c}\text { Cure } \\
{[\%(\mathrm{No})]} \\
31.05 \% \\
(141)\end{array}$ & $\begin{array}{c}\text { Treatment } \\
\text { Completed } \\
{[\%(\text { No.)] }} \\
51.76 \% \\
(235)\end{array}$ & $\begin{array}{c}\text { Defaulter } \\
\text { [\% (No.)] } \\
7.70 \% \\
(35)\end{array}$ & $\begin{array}{c}\text { Failure } \\
{[\%(\mathrm{No})]} \\
4.18 \% \\
\text { (19) }\end{array}$ & $\begin{array}{c}\text { Relapse } \\
{[\% \text { (No.)] }} \\
0.22 \% \\
\text { (1) }\end{array}$ & $\begin{array}{c}\text { Expired } \\
{[\% \text { (No.)] }} \\
3.96 \% \\
(18)\end{array}$ & $\begin{array}{c}\text { Transfer } \\
\text { Out } \\
{[\%(N o)]} \\
1.10 \% \\
(5)\end{array}$ & $\begin{array}{c}\text { Total } \\
454\end{array}$ \\
\hline Cat-I & $\begin{array}{c}85.75 \% \\
(313)\end{array}$ & $\begin{array}{c}27.39 \% \\
(100)\end{array}$ & $\begin{array}{c}58.35 \% \\
(213)\end{array}$ & $\begin{array}{c}6.02 \% \\
(22)\end{array}$ & $\begin{array}{c}2.73 \% \\
(10)\end{array}$ & $\begin{array}{c}0.00 \% \\
(0)\end{array}$ & $\begin{array}{c}4.38 \% \\
(16)\end{array}$ & $\begin{array}{c}1.09 \% \\
(4)\end{array}$ & $\begin{array}{c}80.39 \% \\
(365)\end{array}$ \\
\hline
\end{tabular}




\begin{tabular}{|c|c|c|c|c|c|c|c|c|c|}
\hline Cat-II & $\begin{array}{c}70.78 \% \\
(63)\end{array}$ & $\begin{array}{c}46.06 \% \\
(41)\end{array}$ & $\begin{array}{c}24.71 \% \\
(22)\end{array}$ & $\begin{array}{c}14.60 \% \\
(13)\end{array}$ & $\begin{array}{c}10.11 \% \\
(9)\end{array}$ & $\begin{array}{c}1.12 \% \\
(1)\end{array}$ & $\begin{array}{c}2.24 \% \\
(2)\end{array}$ & $\begin{array}{c}1.12 \% \\
(1)\end{array}$ & $\begin{array}{c}19.61 \% \\
(89)\end{array}$ \\
\hline Male & $\begin{array}{c}75.93 \% \\
(202)\end{array}$ & $\begin{array}{c}30.82 \% \\
(82)\end{array}$ & $\begin{array}{c}45.11 \% \\
(120)\end{array}$ & $\begin{array}{c}10.52 \% \\
(28)\end{array}$ & $\begin{array}{c}5.26 \% \\
(14)\end{array}$ & $\begin{array}{c}0.37 \% \\
\text { (1) }\end{array}$ & $\begin{array}{c}6.01 \% \\
(16)\end{array}$ & $\begin{array}{c}1.87 \% \\
(5)\end{array}$ & $\begin{array}{c}58.60 \% \\
(266)\end{array}$ \\
\hline Female & $\begin{array}{c}92.55 \% \\
(174)\end{array}$ & $\begin{array}{c}31.38 \% \\
(59)\end{array}$ & $\begin{array}{c}61.17 \% \\
(115)\end{array}$ & $\begin{array}{c}3.72 \% \\
(7)\end{array}$ & $\begin{array}{c}2.65 \% \\
(5)\end{array}$ & $\begin{array}{c}0.00 \% \\
(0)\end{array}$ & $\begin{array}{c}1.06 \% \\
(2)\end{array}$ & $\begin{array}{c}0.00 \% \\
(0)\end{array}$ & $\begin{array}{c}41.40 \% \\
(188)\end{array}$ \\
\hline PTB & $\begin{array}{c}78.56 \% \\
(253)\end{array}$ & $\begin{array}{c}43.78 \% \\
(141)\end{array}$ & $\begin{array}{c}34.78 \% \\
(112)\end{array}$ & $\begin{array}{c}9.94 \% \\
(32)\end{array}$ & $\begin{array}{c}5.59 \% \\
(18)\end{array}$ & $\begin{array}{c}0.31 \% \\
\text { (1) }\end{array}$ & $\begin{array}{c}4.34 \% \\
(14)\end{array}$ & $\begin{array}{c}1.24 \% \\
(4)\end{array}$ & $\begin{array}{c}70.92 \% \\
(322)\end{array}$ \\
\hline EBTB & $\begin{array}{c}93.18 \% \\
(123)\end{array}$ & $\begin{array}{l}0.00 \% \\
(0)\end{array}$ & $\begin{array}{c}93.18 \% \\
(123)\end{array}$ & $\begin{array}{c}2.27 \% \\
\text { (3) }\end{array}$ & $\begin{array}{l}0.75 \% \\
\text { (1) }\end{array}$ & $\begin{array}{c}0.00 \% \\
(0)\end{array}$ & $\begin{array}{c}3.03 \% \\
(4)\end{array}$ & $\begin{array}{c}0.75 \% \\
\text { (1) }\end{array}$ & $\begin{array}{c}29.07 \% \\
(132)\end{array}$ \\
\hline
\end{tabular}

\begin{tabular}{|c|c|c|c|}
\hline & $\begin{array}{c}\text { Cure } \\
{[\%(\text { No.) }]} \\
71.21 \%(141)\end{array}$ & $\begin{array}{c}\text { Other Outcomes } \\
{[\%(\text { No.) }] 28.79 \%(57)}\end{array}$ & $\begin{array}{c}\text { Total Sputum Positive } \\
{[\%(\text { No.) }] ~ 198}\end{array}$ \\
\hline Cat-I & $75.75 \%(100)$ & $24.25 \%(32)$ & $66.67 \%(132)$ \\
\hline Cat-II & $62.12 \%(41)$ & $37.88 \%(25)$ & $33.33 \%(66)$ \\
\hline Male & $63.07 \%(82)$ & $36.93 \%(48)$ & $34.65 \%(130)$ \\
\hline Female & $85.76 \%(59)$ & $13.24 \%(9)$ & $(68)$ \\
\hline \multicolumn{2}{|c|}{ Table 2. Outcome of Exclusive Sputum Positive Patients in different Category and Sex }
\end{tabular}

\begin{tabular}{|c|c|c|c|c|c|c|c|c|c|}
\hline $\begin{array}{l}\text { Age Group } \\
\text { (Years) }\end{array}$ & $\begin{array}{c}\text { Treatment } \\
\text { Successful } \\
{[\% \text { (No.)] }}\end{array}$ & $\begin{array}{c}\text { Cure } \\
{[\%(\text { No) }]}\end{array}$ & $\begin{array}{c}\text { Treatment } \\
\text { Completed } \\
{[\%(\mathrm{No} .)]}\end{array}$ & $\begin{array}{l}\text { Defaulted } \\
\text { [\% (No.)] }\end{array}$ & $\begin{array}{c}\text { Failure } \\
{[\%(\mathrm{No})]}\end{array}$ & $\begin{array}{c}\text { Relapse } \\
{[\%(\mathrm{No})]}\end{array}$ & $\begin{array}{c}\text { Expired } \\
{[\%(\mathrm{No})]}\end{array}$ & $\begin{array}{c}\text { Transferred } \\
\text { Out } \\
{[\%(\mathrm{No})]}\end{array}$ & $\begin{array}{c}\text { Total } \\
{[\%(\mathrm{No})]}\end{array}$ \\
\hline $\begin{array}{l}0-14 \\
\text { Yrs. }\end{array}$ & $\begin{array}{c}98.18 \% \\
(54)\end{array}$ & $\begin{array}{c}3.63 \% \\
(2)\end{array}$ & $\begin{array}{c}94.54 \% \\
(52)\end{array}$ & $\begin{array}{c}1.81 \% \\
\text { (1) }\end{array}$ & $\begin{array}{c}0.00 \% \\
(0)\end{array}$ & $\begin{array}{c}0.00 \% \\
(0)\end{array}$ & $\begin{array}{c}0.00 \% \\
(0)\end{array}$ & $\begin{array}{c}0.00 \% \\
(0)\end{array}$ & $\begin{array}{c}12.11 \% \\
(55)\end{array}$ \\
\hline $\begin{array}{c}15-25 \\
\text { Yrs. }\end{array}$ & $\begin{array}{c}85.91 \% \\
(122)\end{array}$ & $\begin{array}{c}37.32 \% \\
\text { (53) }\end{array}$ & $\begin{array}{c}48.59 \% \\
(69)\end{array}$ & $\begin{array}{c}6.33 \% \\
\text { (9) }\end{array}$ & $\begin{array}{c}4.92 \% \\
(7)\end{array}$ & $\begin{array}{c}0.00 \% \\
(0)\end{array}$ & $\begin{array}{c}2.11 \% \\
\text { (3) }\end{array}$ & $\begin{array}{c}0.70 \% \\
\text { (1) }\end{array}$ & $\begin{array}{c}31.27 \% \\
(142)\end{array}$ \\
\hline $\begin{array}{c}26-35 \\
\text { Yrs. }\end{array}$ & $\begin{array}{c}84.46 \% \\
(87)\end{array}$ & $\begin{array}{c}33.98 \% \\
(35)\end{array}$ & $\begin{array}{c}50.48 \% \\
(52)\end{array}$ & $\begin{array}{c}8.73 \% \\
(9)\end{array}$ & $\begin{array}{c}3.88 \% \\
(4)\end{array}$ & $\begin{array}{c}0.00 \% \\
(0)\end{array}$ & $\begin{array}{c}1.94 \% \\
(2)\end{array}$ & $\begin{array}{c}0.97 \% \\
(1)\end{array}$ & $\begin{array}{c}22.68 \% \\
(103) \\
\end{array}$ \\
\hline $\begin{array}{c}36-45 \\
\text { Yrs. }\end{array}$ & $\begin{array}{c}85.48 \% \\
(53)\end{array}$ & $\begin{array}{c}37.09 \% \\
(23)\end{array}$ & $\begin{array}{c}48.38 \% \\
(30)\end{array}$ & $\begin{array}{l}4.83 \% \\
\text { (3) }\end{array}$ & $\begin{array}{l}6.45 \% \\
(4)\end{array}$ & $\begin{array}{c}0.00 \% \\
(0)\end{array}$ & $\begin{array}{c}1.61 \% \\
(1)\end{array}$ & $\begin{array}{c}1.61 \% \\
\text { (1) }\end{array}$ & $\begin{array}{c}13.65 \% \\
(62)\end{array}$ \\
\hline $\begin{array}{c}\text { Above } 45 \\
\text { Yrs. }\end{array}$ & $\begin{array}{c}65.21 \% \\
(60)\end{array}$ & $\begin{array}{c}30.43 \% \\
(28)\end{array}$ & $\begin{array}{c}34.78 \% \\
(32)\end{array}$ & $\begin{array}{c}14.13 \% \\
(13)\end{array}$ & $\begin{array}{c}4.34 \% \\
(4)\end{array}$ & $\begin{array}{c}1.08 \% \\
(1)\end{array}$ & $\begin{array}{c}13.04 \% \\
(12)\end{array}$ & $\begin{array}{c}2.17 \% \\
(2)\end{array}$ & $\begin{array}{c}20.26 \% \\
(92)\end{array}$ \\
\hline Total & $\begin{array}{c}82.81 \% \\
(376)\end{array}$ & $\begin{array}{c}31.05 \% \\
(141)\end{array}$ & $\begin{array}{c}51.76 \% \\
(235)\end{array}$ & $\begin{array}{c}7.70 \% \\
(35)\end{array}$ & $\begin{array}{c}4.18 \% \\
(19)\end{array}$ & $\begin{array}{c}0.22 \% \\
\text { (1) }\end{array}$ & $\begin{array}{c}3.96 \% \\
(18)\end{array}$ & $\begin{array}{l}1.10 \% \\
\text { (5) }\end{array}$ & 454 \\
\hline
\end{tabular}

\section{DISCUSSION}

This present study was done to categorise the treatment outcome and efficacy of ATT drugs in tuberculosis patients put on DOTS in RNTCP. In this study, higher proportion of males (58.60\%) were affected by TB as compared to females. Similar results were observed in studies at different part of India including Aurangabad (62.4\%), Delhi (67.6\%), Nagpur $(69.50 \%)$ and south India.[13,14,15] In this study $41.40 \%$ (188/454) female patients were registered, while $30.49 \%$, $32.40 \%$ and $37.60 \%$ female patients were registered in various studies i.e. Nagpur, Delhi, Aurangabad respectively.[14,15,16] Comparatively higher percentages of female patients were observed in our study that may be due to effort made by our team for active case detection, education, effective counselling and motivation in patient's family members, especially ladies who receive less attention regarding health check-up.

In this study maximum patients $31.27 \%(142 / 454)$ were registered in the age group of $15-25$ years, which reflects that tuberculosis disease is more commonly affecting young adult population. Maximum $36.18 \%$ and $26.4 \%$ patients were observed in study at Nagpur and Aurangabad respectively in age group of 25 - 34 years.[15,16]

Among the age group of 15 - 25 years in present study showed $37.32 \%$ cured and $48.59 \%$ completed treatment. This data coincides with $31.80 \%$ cured and $45.50 \%$ completed treatment in age group of 15 - 24 years in a study done at Aurangabad.[16] Majority of patients 67.62\% (307/454) belonged to 15 - 45 years' age group, which is reproductive and working population in both males and females which can change the scenario of economy of any country.

In this study successful treatment rate observed were $85.75 \%(313 / 365)$ and $70.78 \%(63 / 89)$ in category I and category II respectively, which coincides with $86.00 \%$ and $70.50 \%$ of national average. ${ }^{[5]}$ The overall treatment success was $82.81 \%$ (376/454) in present study, while $89.90 \%$ was found in study of Aurangabad.[15] The cure rate among category I was calculated $27.39 \%(100 / 365)$ in this study. This data coincides with $35.23 \%$ among cat I (old cat III patient also included in an Indian study).[16]

Overall default rate in this study is $7.70 \%$ (35/454), which coincides with same rate $7.70 \%$ in a study done at Delhi.[14] Present study showed default rate of $6.02 \%$ $(22 / 365)$ and $14.60 \%(13 / 89)$ in category I and category II respectively. The average rate of default in India were $4 \%$ among category I and $15.7 \%$ in category II.[6] Continuing education and motivation can reduce defaults at all stage of treatment. As age advanced, percentage of defaulters were increased in this study from $1.81 \%(1 / 55)$ in 0 - 14 years' age group to $14.13 \%$ (13/92) in age group above 45 years.

The percentage of defaulters was high among males, $10.52 \%$ (28/266). Possible causes of default may be feeling of well-being in early phase of treatment, side effect of drugs, 
facing difficulty to attend DOTS centre, financial loss on day of medication due to absence from work, social stigma to attend DOTS centre, rude behaviour of some DOTS provider, less faith towards government health organisation and migration of labourers. To reduce default rate and increase case detection, it is suggested that government should also provide ATT under DOTS by mobile van with in-built facilities of sputum smear examination, portable chest x-ray machine, trained staff and medicines to treat side effect of ATT.

Dense population, little health awareness, increasing trend of nuclear family, unhealthy lifestyle, lesser preemployment health check-up of maid/ driver and affecting young adults are major risk factors for delayed diagnosis, delay in starting of treatment and increasing burden of category I TB and later Category II/ DRTB which can affect individual family condition and economy of country as well.

All family members, close contact of specially sputum positive patients should be strictly evaluated for early detection of tuberculosis and early starting of ATT.

In present study overall failure rate was observed in $4.18 \%(19 / 454)$, while $2.73 \%(10 / 365)$ and $10.11 \%(9 / 89)$ were calculated in category I and category II respectively. Failure rate of $1.04 \%$ and $8.30 \%$ were reported in cat I and cat II in study done at Nagpur.[15] However, it was comparable with average rate of India, $1.5 \%$ and $5.6 \%$ for category I and category II respectively.[6]

As per RNTCP data the prevalence of EPTB in non-HIV patients was $15 \%$ - $20 \%$, but in this study it was $29.07 \%$ which is more than the RNTCP statistics. This increase in prevalence of EPTB is due to easy availability of advanced diagnostic facilities at low cost in medical college setup [17] and ours is a tertiary care referral centre.

Overall death rate in this study observed was 3.96\% (18/454), which coincides with national average of $4.00 \%{ }^{[18]}$

In this study among cases of pulmonary tuberculosis observations were as follows:- $43.78 \%$ (141/322) cured, $34.78 \%(112 / 322)$ completed treatment and 4.34\% (14/322) died. These data coincides with $41.4 \%, 38.3 \%$ and $2.90 \%$ of patients who were found cured, completed treatment and died in a study done at Aurangabad.[16]

It was observed that treatment successful rate were low, but default rate and mortality rate were high among elderly patients aged above 45 years. Similar observations were seen in an Indian study from Aurangabad.[16] Tuberculosis in this age group is most often associated with reactivation of endogenous infection, poor nutritional status, comorbidities, atypical clinical features, delayed diagnosis and neglected by some family members, so patients seek medical advice in more advanced stage which can lead to higher mortality.

This study shows that anti-tuberculosis treatment under DOTS in RNTCP is running successfully in the study region with good success rate and low default rates.

This study had several limitation. The main limitation is that being a retrospective and tertiary care level hospital based study, finding cannot be generalised/ applied to the whole community, but it gives important information regarding tuberculosis management under DOTS in Bhopal, MP (India).

\section{CONCLUSION}

This study showed that tuberculosis disease is now more commonly affecting young adult population, which is a very worrisome fact. In different age groups, percentages of patients observed were $12.11 \% \quad(55 / 454), \quad 31.27 \%$ $(142 / 454), 22.68 \% \quad(103 / 454), 13.65 \% \quad(62 / 454)$ and $20.26 \%$ (92/454) in 0-14 years, $15-25$ years, 26-35 years, 3645 years and above 45 years respectively.

Overall, treatment outcomes were observed as follows $82.81 \%$ (376) treatment successful, $7.70 \%$ (35) defaulted, $4.18 \%$ (19) failed and $3.96 \%$ (18) died.

Higher percentage of treatment success was $98.18 \%$ $(54 / 55)$ observed in the age group of $0-14$ years as compared to other age group. Higher percentage of both defaulters (14.13\%), mortality (13.04\%) with lower treatment successful rate $(65.21 \%)$ were observed in the age group of above 45 years as compared to other age groups.

\section{ACKNOWLEDGEMENT}

The authors express deep gratitude to all RNTCP officials including Dr. Lokendra Dave (Chairman, STF, RNTCP, MP), Dr. Atul Kharate (STO, MP), DTO, Bhopal and MO-RNTCP (JK Hospital) for the use of DOTS centre data. Additionally, we would like to thank all the patients, DOTS provider and Microscopy Technician at DOTS centre. We also recognised the peer reviewers whose suggestions greatly improved this manuscript as well as Astha Agrahari, Divyansh, Vikrant and Kashish.

Permission received from-IEC \& RNTCP Department.

\section{List of Abbreviations}

EPTB: Extra-pulmonary tuberculosis.

PTB: Pulmonary tuberculosis.

TB: Tuberculosis.

RNTCP: Revised National Tuberculosis Control Programme. DOTS: Directly Observed Treatment Short course chemotherapy.

HIV: Human Immunodeficiency Virus.

DR: Drug Resistance.

DM: Diabetes Mellitus.

\section{REFERENCES}

[1] Tuberculosis Fact sheet No. 104. World Health Organization. November 2010. Retrieved 26 July 2011 www.who.int/mediacentre/factsheets/fs104/en/(1)

[2] Stop TB. Partnership and World Health Organization. An International Roadmap for Tuberculosis Research, Geneva: World Health Organization, 2011.

[3] Managing the Revised National Tuberculosis Control Programme in your area. A training course-modules (1-4)-Central TB Division, New Delhi: Directorate General of Health Services, Ministry of Health and Family Welfare Nirman Bhavan. Government of India. 2010: p. 1.

[4] Global Tuberculosis Control 2014. Geneva: WHO, 2014.

www.who.int/tb/publications/global_report/en/.

[5] District wise performance of RNTCP. TB India 2011:114-5. http://www.tbcindia.org. ISBN 81902652-5-3

[6] TB India 2006, RNTCP status report. Central TB Division, Directorate General of Health Services, Ministry of Health and Family Welfare, Nirman Bhavan, New Delhi 2006: p. 12, 56-8. 
[7] TB Statistics for India - TB Facts.org 2012. http://wwwtbfacts.org/tb-statics-india.html.

[8] Kumar R, Ahirwar RK, Dave L, et al. A study of weight variation during anti-tuberculosis treatment in tuberculosis patients put on DOTS in RNTCP in Central India. J Evolution Med Dent Sci 2017;6(6):478-81. https://jemds.com/data_pdf/1_Lokendra\%20Dave.pdf

[9] Nagpual DR. India's National Tubercitlosis program an overview. Intl J Tub 1989:36, 2005.

[10] Narain JP, Lo YR. Epidemiology of HIV-TB in Asia. Indian J Med Res 2004;120(4):277-89.

[11] Khatri GR, Frieden TR. The status and prospectus of Tuberculosis control in India. Int J Tuberc Lung Dis 2000;4(3):193-200.

[12] TB India 2007 - RNTCP status report. Central Tuberculosis Division, New Delhi. March, 2007: p. 106. http://www.tbcindia.org ISBN 81-902652-2-9.

[13] Holmes CB, Hausler H, Nunn P. A review of sex differences in the epidemiology of tuberculosis. Int J Tuberc Lung Dis 1998;2(2):96-104.

[14] Chadha SL, Bhagi RP. Treatment outcome in Tuberculosis patients placed under directly observed treatment short course (DOTS): a cohort study. Indian J Tuberc 2000;47:155-8.
[15] Choudhary S, Tayade B, Keshwani P. Efficacy and treatment outcome of DOTS in RNTCP. Panacea Journal of Medical Sciences 2012;2(1):32-6. http://pjms.in/index.php/panacea/article/view/77

[16] Karanjekar VD, Lokare PO, Gaikwad AV, et al. Treatment outcome and follow up of Tuberculosis patients put on directly observed treatment shortcourse under Rural Health Training Center, Paithan, Aurangabad in India. Ann Med Health Sci Res 2014;4(2):222-6.

http://www.ncbi.nlm.nih.gov/pubmed/24761242

[17] Shrivastava AK, Brahmachari S, Kumar Ratan, et al. Clinico- Epidemiological Profile of Extra-pulmonary Tuberculosis in Central India. Int J Med Res Rev 2015;3(2):223-30.

http://www.ijmrr.in/ AuthorUpload/471PA.pdf

[18] Central TB Division, Directorate General of Health Services, Ministry of Health and Family Welfare, Nirman Bhavan, New Delhi 110011. http://www.tbcindia.org (Accessed on May April 2006). 